\title{
GEOGRAFIJA V VRTCIH IN NA RAZREDNI STOPNJI OSNOVNE ŠOLE V SLOVENIJI
}

\section{Dr. Maja Umek}

Oddelek za razredni pouk, Pedagoška fakulteta Univerze v Ljubljani

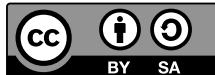

Kardeljeva ploščad I5, SI-I000 Ljubljana

e-mail: Maja.Umek@pef.uni-lj.si

Pregledni znanstveni članek

COBISS 1.02

DOI: $10.4312 /$ dela.43.4.61-75

\section{Izvleček}

Prispevek daje odgovore na vprašanja: koliko in s katerimi vsebinami je geografija vključena $\mathrm{v}$ učne načrte od predšolskega obdobja do vključno petega razreda osnovne šole, v kolikšnem količinskem razmerju je do drugih predmetnih področij in za katere spremembe učnih načrtov bi si bilo potrebno prizadevati pri naslednjih prenovah. Analizirali smo učne načrte, v katere so vključene geografske vsebine. Uporabili smo kvalitativno in semikvantitativno analizo. Kategorije za kvalitativno analizo so bile pokrajinske sestavine oziroma njihove prvine, pokrajine ter orientacija in kartografija.

Ključne besede: geografske vsebine, učni načrt, vrtec, razredni pouk

\section{GEOGRAPHY IN KINDERGARTENS AND AT THE LOWER LEVEL OF PRIMARY SCHOOL IN SLOVENIA}

\begin{abstract}
The paper elucidates to what extent and with what contents geography is included in syllabuses from the preschool period to the fifth grade, its quantity relation to other subjects, and syllabus changes to be sought in future reforms. We analysed curriculums that incorporate geographical contents, with the use of qualitative and semi-quantitative analysis. Encoding categories comprised landscape elements, regions, orientation and cartography.
\end{abstract}

Key words: geographical learning, curriculum, kindergarten, primary-level teaching 


\section{UVOD}

Raziskovalna skupina pod vodstvom dr. Jurija Kunaverja je leta 2002 zaključila evalvacijo kurikularne prenove geografije, ki je zajela pouk geografije od šestega do devetega razreda osnovne šole ter geografijo na srednjih šolah. Med drugim so ugotovili, da je »vertikalna razvrstitev geografske snovi v osnovni šoli dovolj smiselna in organska« (Kunaver in sod., 2002, str. 52). V raziskavo niso vključili nižjih razredov osnovne šole, kjer so geografske vsebine del interdisciplinarnih učnih predmetov Spoznavanje okolja, Družba ter Naravoslovje in tehnika. Namen tega prispevka je osvetliti in evalvirati vključenost geografskih vsebin na nižjih stopnjah vzgoje in izobraževanja, od vrtca do konca razredne stopnje, kjer geografskih vsebin ne poučujejo učitelji geografije.

Predšolsko obdobje je posebno obdobje v razvoju otroka, v katerem so po mnenju nekaterih avtorjev, npr. Marie Montessori (Batistič Zorec, Krnel, 2009, str. 50), potenciali za učenje največji. V tem obdobju se približno pri tretjem letu starosti zgodi prehod od spontanega k reaktivnem učenju. Do tretjega leta se otrok pretežno uči po 'osebnem programu', sledi prehod na spontano-reaktivno učenje, kjer otrok že sprejema ponujeni program odraslih, če je zanj privlačen (Sutherland, 1992). V predšolski vzgoji sta se večkrat zamenjala dva pogleda na otroštvo in učenje v tem obdobju: prvi je zagovarjal načrtno in sistematično učenje s strukturiranimi programi kot pripravo na šolo, drugi pa brezskrbno, igrivo otroštvo, s poudarkom na socialno-čustvenem razvoju, kognitivni razvoj in učenje pa sta bila zapostavljena (Batistič Zorec, 2002).

Sedanji slovenski kurikulum za vrtce, potrjen leta 1999, poskuša biti v ravnotežju med obema skrajnostma. Je procesno-razvojno naravnan in poudarja odprtost, pestro, raznoliko in uravnoteženo ponudbo različnih področij ter avtonomijo vrtcev. Opredeljuje pet področij dejavnosti. Te »predstavljajo okvir, znotraj katerega so vsebine in dejavnosti strokovna ponudba vzgojiteljem. Na ravni izvedbenega kurikuluma vzgojitelji predlagane vsebine in dejavnosti na različne načine povezujejo, dograjujejo in dopolnjujejo...« (Kurikulum za vrtce, 2007, str. 25). Iz navedenega sledi, da imajo zapisane dejavnosti, kljub odprtosti kurikuluma, prednost pred drugimi že zato, ker so eksplicitno navedene.

Pri izdelavi Kurikuluma za vrtce (2007) je sodelovalo 29 strokovnjakov, od tega so bili glede na izobrazbo vključeni biolog, kemik, matematik, jezikoslovec, diplomant primerjalne književnosti, filozof, muzikolog, profesor športne vzgoje, diplomanti likovne umetnosti, dramske igre, glasbe in plesa, psiholog, pedagog, specialni rehabilitacijski pedagog in vzgojitelj predšolskih otrok. S področja družboslovnih in humanističnih ved, ki se v obveznem izobraževanju ukvarjajo z vzgojo in izobraževanjem (npr. zgodovinarji, sociologi, geografi), ni bilo v skupini nikogar. V pripravo kurikuluma predmetni strokovnjaki niso bili vključeni. Mnenja tistih, ki se ukvarjajo z vzgojo in izobraževanjem v predšolskem obdobju, o vključevanju strokovnjakov različnih predmetnih področij so različna. Kroflič (2001, str. 14) npr. meni, da bi morali sodelovati predmetni strokovnjaki vseh obveznih osnovnošolskih predmetov, kurikularni teoretiki pa bi morali s temeljnimi usmeritvami poskrbeti, da ne bi prišlo do prevelikega 'pošolanja' vrtca.

$\mathrm{V}$ osnovnošolskem predmetniku je geografija kot samostojen predmet umeščena od šestega do devetega razreda, v učnem procesu pa so geografski učni cilji in vsebine že 
tradicionalno vključeni od prvega razreda naprej. V prvem vzgojnoizobraževalnem obdobju, od prvega do tretjega razreda, je to v okviru predmeta Spoznavanje okolja, v četrtem in petem razredu pa pri predmetih Družba ter Naravoslovje in tehnika. Način in podrobnost določanja učne vsebine v učnih načrtih (to poimenovanje se je ohranilo za predmetne kurikulume) sta odvisna od okvirjev in zahtev, ki jih določijo kurikularni strokovnjaki na osnovi teoretskih predpostavk nacionalnega kurikuluma. To sta bili v devetdesetih letih prejšnjega stoletja v Sloveniji Bela knjiga o vzgoji in izobraževanju v Republiki Sloveniji (1995) in Izhodišča kurikularne prenove v R Sloveniji (1996). Slednje so nadgradile Smernice, načela in cilji posodabljanja učnih načrtov (2007), na katerih je slonel proces posodobitve, ki se je zaključil s potrditvijo posodobljenih učnih načrtov za osnovno šolo leta 2011.

Glavna načela, na katerih temeljijo prenovljeni slovenski učni načrti iz leta 2011, so:

- avtonomija učitelja in šole;

- jasna vodilna ideja predmeta;

- učnociljni in procesno-razvojni model pouka;

- odprtost in izbirnost (fleksibilnost učnega procesa);

- kompetentnost;

- kakovost znanja;

- razvoj metakognitivnih sposobnosti učencev;

- razvojno spremljanje učenčevih dosežkov;

- povezovanje predmetov in disciplin - globalni pristop, ki spodbuja celostno učenje in poučevanje (Žakelj, 2014a).

Kriteriji pri izbiri vsebine za posamezni osnovnošolski predmet so bili: znanstvena primernost in aktualnost, ustrezen obseg vsebine, primerna dinamika obravnave ter usklajenost po vertikali in horizontali. Pri ciljih naj bi ob prenovi leta 2011 dosegli premik od strogega učnociljnega pristopa k procesno-razvojnemu modelu oziroma od poznavanja vsebin in podatkov k obvladovanju strategij pridobivanja in uporabe novih znanj (Žakelj, 2014b). Z vidika naše analize je pomembna uvedba izbirnosti v učne načrte, čeprav v majhnem obsegu, kar omogoča učitelju in učencu delno avtonomno odločanje pri izbiri podrobnejših ciljev in vsebin.

Med avtorji učnih načrtov za razredno stopnjo osnovne šole, ki vključujejo tudi geografske vsebine, je le en geograf. To je avtorica tega prispevka, ki je sodelovala pri pisanju učnega načrta za predmet Družba in bila recenzentka pri učnem načrtu za predmet Spoznavanje okolja. Pri učnem načrtu za predmet Naravoslovje in tehnika geografi nismo sodelovali.

\section{EVALVACIJA}

\section{I Namen in metodologija evalvacije}

Namen evalvacije je ovrednotiti vključenost geografije v kurikulume na nižjih stopnjah vzgoje in izobraževanja, od vrtca do konca razredne stopnje. Postavili smo naslednja raziskovalna vprašanja: 
- S katerimi vsebinami in učnimi cilji je geografija vključena $\mathrm{v}$ učne načrte od predšolskega obdobja do konca razredne stopnje?

- V kakšnem razmerju so geografske vsebine do vsebin drugih ved, zlasti do vsebin zgodovine in naravoslovja?

- Kateri geografski vzgojnoizobraževalni cilji in vsebine so vključeni v učne načrte predmetov Spoznavanje okolja, Družba ter Naravoslovje in tehnika in kateri ne?

- Za katere spremembe učnih načrtov bi si bilo potrebno prizadevati pri naslednjih prenovah?

Metodološko gre za racionalno evalvacijo ter kvalitativno analizo in vrednotenje učnih načrtov. Uporabili smo tudi semikvantitativno analizo, podatke pa smo obdelali z opisno statistiko. $V$ učnih načrtih smo iskali učne vsebine, dejavnosti in cilje naslednjih učnih sklopov:

- spoznavanje pokrajinskih elementov oziroma njihovih značilnosti (relief, kamnine in geološka zgradba, podnebje, vodovje, prst, rastlinstvo in živalstvo, prebivalstvo, naselja, gospodarstvo);

- spoznavanje različnih pokrajin (od neposredne okolice, domače pokrajine, slovenskih pokrajin do Evrope in sveta);

- razvijanje spretnosti orientiranja in dela z zemljevidi;

- oblikovanje odnosa, stališč, ustreznega ravnanja v duhu trajnostnega razvoja s poudarkom na okoljski vzgoji.

Analizirali smo vsebinsko strukturo in cilje kurikuluma za vrtce ter učnih načrtov za predmete Spoznavanje okolja, Družba ter Naravoslovje in tehnika. Predpostavili smo, da otroci pri spoznavanju geografskih vsebin razvijajo tudi geografske spretnosti, tako specifične kot splošne, ki jim omogočajo vsebinsko in učnoprocesno nadgradnjo. Izjema sta orientacija in kartografija, ki ju zaradi procesne naravnanosti analiziramo posebej.

\subsection{Kurikulum za vrtce}

Kurikulum za vrtce (2007) je nacionalni dokument. Sprejet je bil leta 1999 in je strokovna podlaga za izvajanje različnih programov javnega vrtca za otroke od prvega do šestega leta starosti. Tiskana različica Kurikuluma za vrtce obsega 56 strani. Vsebina je podana v štirih glavnih poglavjih: Cilji Kurikuluma za vrtce, Načela uresničevanja ciljev, Otrok v vrtcu ter Področja dejavnosti v vrtcu. V slednjem, najobsežnejšem poglavju, so opredeljeni vzgojnoizobraževalni cilji in dejavnosti po naslednjih področjih: gibanje, jezik, umetnost, družba, narava in matematika.

Za vsako področje je v uvodu izpostavljen osnovni namen dejavnosti, kar je podobno kot poglavje Opredelitev predmeta v učnih načrtih za osnovno šolo. Sledijo cilji, od splošnih h konkretnejšim, na treh nivojih (1) globalni cilji, (2) cilji ter (3) dejavnosti. Cilji in dejavnosti imajo vlogo operativnih ciljev. Dejavnosti so zapisane posebej za otroke od prvega do tretjega leta starosti in posebej za otroke od tretjega do šestega leta. Sledi še rubrika Vloga odraslih, ki je podobna didaktičnim navodilom v osnovnošolskih učnih načrtih. 
Področje Družba. »Človek je del družbenega okolja, v katerem raste, živi in deluje. Da bi lahko otroci sodelovali z okoljem, vplivali nanj in ga pozneje aktivno spreminjali, morajo postopoma spoznati bližnje družbeno okolje ... in hkrati dobivati vpogled v širšo družbo. Otroci spoznajo svoj domači kraj in se seznanijo s tem, kako so ljudje tod živeli v prejšnjih časih.« (Kurikulum za vrtce, 2007, str. 48). Razviden je poudarek na spoznavanju bližnjega družbenega okolja, kjer je prostorsko omenjen samo domači kraj. Vsa ostala priporočila so usmerjena v spoznavanje odnosov med ljudmi.

Med globalnimi cilji ni eksplicitno navedenega geografskega ali prostorskega cilja. Implicitno pa je prostor vključen v cilj »spoznavanje ožjega in širšega družbenega in kulturnega okolja ter spoznavanje medkulturnih in drugih razlik« (Kurikulum za vrtce, 2007, str. 50). Med 19 operativnimi cilji zasledimo dva geografska: »otrok razvija interes in zadovoljstvo ob odkrivanju širšega sveta zunaj domačega okolja« ter »otrok spoznava značilnosti okolja, ki so pomembne za lokalno skupnost, npr. reka ali gora v bližini, pokrajinski muzej, arheološke izkopanine, pozneje pa tudi značilnosti širšega okolja« (Kurikulum za vrtce, 2007, str. 51). Med primeri dejavnosti od prvega do šestega leta lahko kot geografske opredelimo naslednje: spoznava domači kraj, spoznava različne ustanove, različne poklice, različna geografska in kulturna okolja, se vživlja v položaj drugih ljudi na osnovi stikov z vrstniki, ki izhajajo iz drugih krajev, dežel, s pomočjo knjig, televizije ... Šele pri najbolj operacionaliziranih ciljih avtorji 'negeografi' prepoznavajo prostor kot dejavnik družbenega življenja (Kurikulum za vrtce, 2007, str. 50-54). V rubriki Vloga odraslih ni vključevanja geografskega vidika, tudi implicitnega ne.

Področje Narava. Že v prvi povedi uvoda je prostor opredeljen kot fizično in družbeno okolje in kot življenjsko okolje otroka, v okviru katerega se razvijajo otrokove sposobnosti, da bi se lahko v okolje dejavno vključeval. V nadaljevanju je poudarjeno otrokovo spoznavanje živali, rastlin, predmetov, pojavov, sprememb v naravi in življenju ljudi glede na letne čase, povezovanje dogodkov v prostoru in času ter usmerjanje otroka $\mathrm{v}$ aktivno delovanje za ohranjanje naravnega okolja (Kurikulum za vrtce, 2007, str. 55-56).

Med šestimi globalnimi cilji lahko prepoznamo dva, ki sta tudi geografska: »doživljanje in spoznavanje žive in nežive narave v njeni raznolikosti, povezanosti, stalnem spreminjanju in estetskih razsežnostih; razvijanje naklonjenega, spoštljivega in odgovornega odnosa do žive in nežive narave«. Od 37 ciljev otroci pri osmih pridobivajo geografsko predznanje z naslednjimi vsebinami: živa in neživa narava v medsebojnem vplivanju, varovanje okolja, vremenski pojavi, planet Zemlja, urejanje prostora, pomen lege ter voda (Kurikulum za vrtce, 2007, str. 56-58). Od 39 dejavnosti jih je deset povezanih s spoznavanjem naravnogeografskega okolja: spoznavanje na terenu, zgodbe različnih narodov o naravi, igre z mivko, zrakom, vodo, snegom, ledom, urejanje prostora, izdelovanje modelov, ločevanje odpadkov (Kurikulum za vrtce, 2007, str. 59-61).

$\mathrm{V}$ navodilih odraslim so tudi napotki, naj otrok spoznava naravo neposredno, v različnem času dneva in ob različnih vremenskih pogojih. Dobro je, da vzgojitelj izkoristiti posebne situacijske dogodke, kot so mavrica, oblaki, luna na nebu, polž na igrišču, ter omogoči situacije, v katerih otrok opisuje prostor z različnih zornih kotov in mu omogoči razvijanje občutka ob lastnem gibanju (Kurikulum za vrtce, 2007, str. 62). 
Področje Matematika. V uvodu in pri globalnih ciljih ni povezave z geografskimi vsebinami. Med cilji, vseh je 16, se dva navezujeta na orientacijo v prostoru. Ne gre za orientacijo v geografskem prostoru, vendar otrok usvaja zanjo pomembne pojme. Cilja sta: »otrok spoznava prostor, njegove meje, zunanjost, notranjost; otrok uporablja izraze za opisovanje položaja predmetov« in »se nauči orientacije v prostoru« (Kurikulum za vrtce, 2007, str. 65).

Med 58 predlaganimi dejavnostmi štiri vključujejo orientacijo v prostoru: »otrok raziskuje igralnice, vso stavbo, dvorišče vrtca; opazuje okolje s tobogana, z vzpetine; hodi po označeni poti, po labirintu v snegu; opazuje, kaj je zunaj in kaj notri; se uči enostavne orientacije v prostoru; opazuje, kje ležijo druge stavbe glede na vrtec, riše načrte po svoji zamisli, po predlogah in po spominu, izdeluje makete stavb in okolice, se igra z zemljevidi« (Kurikulum za vrtce, 2007, str. 71).

Področja Gibanje, Jezik in Umetnost ne vključujejo ciljev in dejavnosti, ki bi bile povezane s spoznavanjem geografskega okolja.

Preglednica 1: Število ciljev in dejavnosti po področjih kurikuluma za vrtce, v katerih so vključene geografske vsebine

Table 1: The number of objectives and activities by curriculum fields for kindergartens that include geography

\begin{tabular}{|l|c|c|c|l|l|}
\hline $\begin{array}{l}\text { Področje } \\
\text { kurikuluma }\end{array}$ & Vsi cilji & $\begin{array}{l}\text { Geografski } \\
\text { cilji }\end{array}$ & Vse dejavnosti & $\begin{array}{l}\text { Geografske } \\
\text { dejavnosti }\end{array}$ & Področje geografije \\
\hline Družba & 19 & 2 & 23 & 7 & družbena in lokalna \\
\hline Narava & 37 & 8 & 39 & 12 & fizična \\
\hline Matematika & 16 & 2 & 58 & 4 & $\begin{array}{l}\text { orientacija in } \\
\text { kartografija }\end{array}$ \\
\hline
\end{tabular}

Vir/Source: Kurikulum za vrtce, 2007

Iz preglednice 1 je razvidno, da so v kurikulumu za vrtce geografske vsebine slabo zastopane. Pomena tako naravnega kot družbenega okolja v njunem prepletanju in soodvisnosti se zavedajo avtorji ciljev in dejavnosti s področja narave, avtorji s področja družbe pa ne. Slednji vključijo spoznavanje domačega kraja in drugih okolij šele bolj na operativni ravni, pri dejavnostih, in to predvsem prek spoznavanja načina življenja ljudi, različnih kulturnih in drugih navad.

\subsection{Učni načrti Spoznavanje okolja, Družba ter Naravoslovje in tehnika}

Učni načrt Spoznavanje okolja (2011). Spoznavanje okolja je učni predmet v prvem vzgojnoizobraževalnem obdobju. Vključuje naravoslovne, družboslovne in tehniške učne cilje ter vsebine. Pri opredelitvi predmeta je geografija omenjena kot ena od vključenih disciplin. 
Med splošnimi cilji predmeta sta dva, ki ju tudi geografi prištevamo 'k svojim': razumevanje okolja in razvijanje spoznavnega področja. Operativni cilji in vsebine so izraženi v obveznih in izbirnih znanjih po tematskih sklopih. Geografska znanja pridobivajo učenci v sedmih tematskih sklopih od dvanajstih.

Tematski sklop Prostor je najbolj geografski. Vseh dvanajst učnih ciljev je geografskih in pokrivajo naslednje vsebine:

- $\quad$ orientacija v prostoru - glavne strani neba, zemljevid, globus;

- območja - domači kraj, domača pokrajina, Slovenija, Evropa, svet;

- pojmi - naselje (mesto, vas), hrib (hribovje), gora (gorovje), ravnina, dolina, reka, potok, morje, cesta, železnica, obdelovalne površine, gozd, puščava, oceani, celine idr.

Učenci spoznavajo različne regije, od domačega kraja do sveta, naravnogeografske in družbenogeografske pojme ter se orientirajo v pokrajini po znanih objektih, po straneh neba ter spoznavajo zemljevid in globus.

V tematskem sklopu Pojavi je osem od enajstih ciljev povezanih s spoznavanjem vremena. Vsebine so: vremenska stanja, vremenski koledar, vremenski pojavi, merjenje padavin. Sklop Živa bitja obsega 21 učnih ciljev, od tega jih je pet povezanih z geografskimi vsebinami: živa in neživa narava, okolje in živa bitja, življenjska okolja, raznovrstnost živega, rastline in živali, medsebojna odvisnost živih bitij.

Približno tretjino učnih ciljev, šest od 19, lahko v vsebinskem sklopu Skupnosti povežemo z geografijo. Pripadajoče vsebine so: ustanove, država Slovenija, prebivalci in državljani Slovenije, Slovenija v Evropi in posredno tudi prazniki doma in po svetu. Naslednji družboslovni sklop Odnosi ima 25 ciljev, tri lahko povežemo z geografijo (poklic, hobi, povezanost in soodvisnost ljudi, držav, celin).

V petih od 14 učnih ciljev v tematskem sklopu Promet učenci pridobivajo tudi geografsko znanje. Vsebine so: prometna sredstva,vrste prometa (sredstva, vloga), vzroki za potovanja, vpliv prometa na okolje. Tematski sklop Okoljska vzgoja bomo opredelili kot geografski, ker je vseh osem učnih ciljev geografskih. Imajo naslednje vsebine: okolje, naravno in grajeno okolje, onesnaževanje okolja, posledice onesnaževanja za živa bitja, odpadki, ravnanje z odpadki, onesnaževalci vode, tal, zraka, varčevanje z energijo, urejanje okolja.

Učni cilji pri Spoznavanju okolja vsebinsko zajemajo vse osnovne tradicionalne dele geografije. Pri regionalni geografiji je poudarek na lokalni geografiji, posamezni cilji pa širijo prostor na Slovenijo, Evropo in svet kot celoto. Orientacija v prostoru se z orientacije po vidnih objektih širi na spoznavanje glavnih strani neba, učenci spoznavajo zemljevid, globus, skice, modele kot prikaze pokrajine in Zemljinega površja. Družbenogeografske teme obsegajo promet, naselja, prebivalstvo, gospodarske dejavnosti, obdelovalne površine, ustanove, države, naravnogeografske teme pa vremenske pojave (predznanje za kasnejše razumevanje podnebja), živali, rastline, neživo naravo, relief. Precejšen poudarek je na okoljski vzgoji, manj pa na drugih vidikih vzgoje za trajnostni razvoj. 
Slika 1: Delež operativnih učnih ciljev pri Spoznavanju okolja po predmetnih področjih Figure 1: The share of operative learning objectives in the integrated course Environment by subject areas

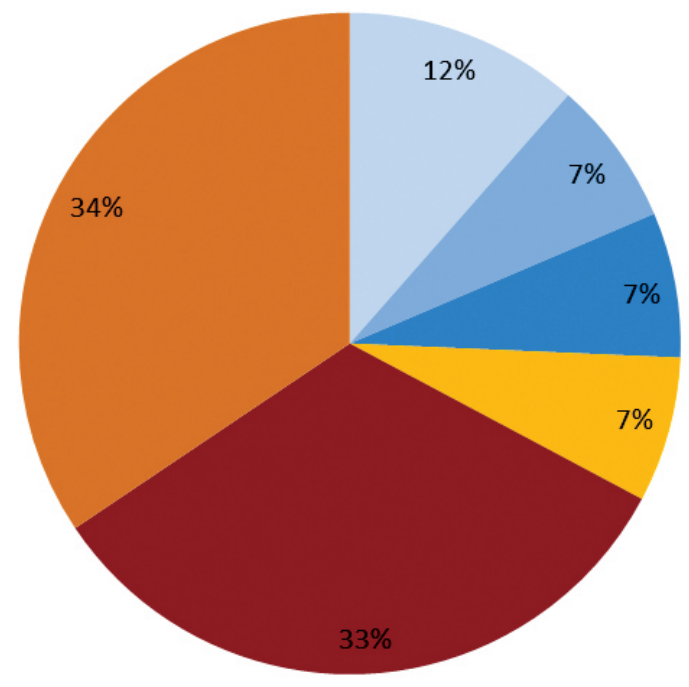

geografija

geografija v okviru naravoslovnih tem

geografija v okviru družboslovnih tem

zgodovina

sociologija brez družbenogeografskih tem

naravoslovje brez fizičnogeografskih tem

Vir/Source: Učni načrt Spoznavanje okolja (2011)

Delitev ciljev med področji je nekoliko poenostavljena, a vseeno kaže ustrezno zastopanost učnih ciljev, ki učence od šestega do osmega leta starosti uvajajo v geografsko spoznavanje zlasti bližnjega okolja in širijo njihovo prostorsko orientacijo na Slovenijo, Evropo in svet. Geografija je ustrezno zastopana v primerjavi z naravoslovnimi vedami, kot so biologija, kemija in fizika, če predpostavimo, da vsaka od njih obsega tretjino naravoslovnih ciljev. Zaostaja pa za sociološkimi cilji, ki jih je nekaj manj kot 60, saj so v tej skupini tudi cilji s področja psihologije, etnologije idr. Povezava geografije z drugimi družboslovnimi in naravoslovnimi področji je uravnotežena.

Učni načrt Družba (2011). Predmet Družba je del predmetnika četrtega in petega razreda osnovne šole in je nadaljevanje predmeta Spoznavanje okolja, ki je v drugem vzgojnoizobraževalnem obdobju razdeljen na Družbo ter Naravoslovje in tehniko. V uvodu je namen predmeta opredeljen kot »spoznavanje razmerja med posameznikom, družbo in naravnim okoljem ... spoznavanje in vrednotenje okolja (družbenega, kulturnega, naravnega), in sicer v vseh njegovih sestavinah ter interakcijah, soodvisnostih med temi sestavinami« (Učni načrt Družba, 2011, str. 4 ). Predmet Družba obsega v četrtem razredu dve uri pouka tedensko, v petem razredu pa tri ure tedensko.

Prva med splošnimi cilji predmeta sta tudi splošna cilja geografske vzgoje in izobraževanja. Poudarjata razumevanje družbenega, kulturnega in naravnega okolja v času in 
prostoru ter zavedanje interakcij, soodvisnosti kulturnih, družbenih, naravnih procesov in pojavov ter pomembnost trajnostnega razvoja. Sledijo temeljni cilji v treh sklopih (Ljudje v družbi, Ljudje v prostoru in Ljudje v času) ter operativni cilji.

Tema Prostorska orientacija in kartografija ima v četrtem in petem razredu skupaj devet operativnih učnih ciljev, ki obsegajo naslednje vsebine: glavne strani neba, orientacija s kompasom in zemljevidi, sestavine zemljevida, branje različnih zemljevidov, skiciranje zemljevidov, kartiranje, terensko delo. Pri temi Domači kraj učenci spoznavajo naravne osnove za nastanek in razvoj kraja, gospodarske in druge dejavnosti, varnost poti in razumejo vlogo posameznika v skupnosti za urejenost kraja ter varovanje okolja. Od šestih ciljev je pet geografskih.

Tema Domača pokrajina ima štiri geografske cilje in naslednje vsebine: naravne značilnosti domače pokrajine (relief, vode, prst, podnebje, kamnine, rudnine), značilnosti in razlike med naselji v domači pokrajini, gospodarske in druge dejavnosti v domači pokrajini, vplivi človeka na spreminjanje narave.

Cilji pri temi Slovenija - lega in značilnosti so precej splošni in samo pet ciljev ne odraža vsebinskega obsega tega sklopa. Učenci spoznajo naravne enote Slovenije, njene naravne in družbene značilnosti, spoznavajo naravno in kulturno dediščino, razvijajo pozitiven odnos do tradicije, spoznavajo značilnosti trajnostnega razvoja.

Več učnih ciljev ima tema Država Slovenija, čeprav je vsebinsko manj obsežna. Osem od devetih ciljev je pomembnih tudi z vidika geografije in zajemajo naslednje vsebine: država, domovina, politična organiziranost slovenske države, simboli, vloga glavnega mesta, prebivalstvo (manjšine, priseljenci, zdomci, izseljenci), organiziranost Evropske unije, povezanost držav Evropske unije.

Preglednica 2: Število učnih ciljev po področjih v učnem načrtu za predmet Družba Table 2: The number of learning objectives by fields in the curriculum for Society

\begin{tabular}{|l|c|c|}
\hline Vsebinski sklopi & Število ciljev & Delež ciljev (\%) \\
\hline Geografske vsebine - Ljudje v prostoru & 30 & 42 \\
\hline Zgodovinske vsebine - Ljudje v času & 12 & 17 \\
\hline Sociološke vsebine - Ljudje v družbi & 29 & 41 \\
\hline Skupaj & 71 & 100 \\
\hline
\end{tabular}

Vir/Source: Učni načrt Družba (2011)

Vseh operativnih učnih ciljev v učnem načrtu za predmet Družba je 71. Geografski in sociološki del sta uravnotežena, premalo pa je učnih ciljev s področja zgodovine. Regionalna geografija obsega pokrajine od domače pokrajine do Evrope in sveta, največji poudarek pa je na spoznavanju slovenskih pokrajin. Čeprav je predmet družbosloven, so v okviru regionalne geografije vključene tudi naravnogeografske vsebine - naravne značilnosti domače in slovenskih pokrajin (relief, vode, prst, podnebje, kamnine, rudnine). Vzgojni vidik je poudarjen v naslednjih vsebinah: vloga posameznika v skupnosti za 
urejenost kraja in varovanje okolja, vplivi človeka na spreminjanje narave, značilnosti trajnostnega razvoja.

Učni načrt Naravoslovje in tehnika (2011). Predmet Naravoslovje in tehnika obsega po tri ure tedensko $\mathrm{v}$ četrtem in petem razredu. V opredelitvi predmeta in splošnih ciljih ni poudarkov, ki bi eksplicitno vključevali geografijo, sta pa omenjena naravno in umetno okolje. Operativni učni cilji so veliko bolj razčlenjeni kot pri Družbi, kar se kaže v trikrat večjem številu ciljev (215). Ciljev, ki jih lahko štejemo tudi kot geografske, je 54 ali četrtina.

V tematskem sklopu Snovi v naravi so teme Voda, Prst in Zrak. Tema Voda ima šest geografskih ciljev, ki vključujejo naslednje vsebine: kroženje vode, morje, površinske vode, podzemne vode, pitna voda, omejenost vodnih virov, onesnaževanje vode, varovanje vode. Temo Prst opredeljuje šest geografskih ciljev z vsebinami: sestavine prsti, lastnosti prsti, vrste prsti glede na okolje, onesnaževanje prsti. Sedem ciljev pa določa temo Zrak, ki ima naslednje vsebine: atmosfera, zrak - zmes plinov, onesnaževanje zraka, rešitve za čistejši zrak, odnos ljudi do onesnaževanja zraka, alternativni viri energije.

V tematskem sklopu Sile in gibanje je podtema Gibanje Zemlje s šestimi geografskimi cilji in naslednjimi vsebinami: vrtenje Zemlje, dan, noč, mrak, prisojna in osojna stran, Lunine mene, Lunin in Sončev mrk.

Tudi v sklopu Pojavi so geografske vsebine. Tema Veter ima pet geografskih učnih ciljev in vključuje naslednje vsebine: nastanek vetrov, merjenje zračnega tlaka, hitrosti vetrov, smeri vetrov, pomen vetra, izkoriščanje vetra, nevarnosti močnih vetrov. Kar 15 geografskih ciljev ima tema Vpliv Sonca na vreme in obsegajo naslednje vsebine: segrevanje snovi 'na soncu', ogrevanje tal, ogrevanje zraka, vpadni kot Sončevih žarkov, ogrevanje prisojnih in osojnih pobočij, segrevanje vode, letni časi in kroženje Zemlje okoli Sonca, spreminjanje temperature zraka $\mathrm{z}$ višino, veter in vreme, cikloni in anticikloni ter smer vetra, prenašanje snovi in toplote $\mathrm{z}$ vetrovi.

Za geografijo potrebno znanje pridobivajo učenci tudi v sklopu Živa bitja. Kot geografske smo izdvojili devet ciljev z naslednjimi vsebinami: vrste rastlin, živali in glive v neposrednem okolju; najbolj značilne kulturne rastline naših krajev; najbolj značilne domače živali naših krajev; izmenjevanje vode med živimi bitji in okoljem; medsebojna odvisnost živih bitij v naravi; živa bitja, prilagojena na okolje; življenje na Zemlji je bilo nekoč drugačno; posledice človekovega nenehnega posega v naravno okolje; trajnostni razvoj.

Večina geografskih ciljev in vsebin v učnem načrtu Naravoslovje in tehnika (2011) je fizičnogeografskih in zajemajo pokrajinske sestavine voda, zrak, prst, živa narava, ne vključujejo pa kamnin in reliefa.

Prostor je pri 54 geografskih ciljih omenjen samo štirikrat, če ne vključujemo ciljev, povezanih z Zemljo kot planetom. Trikrat je omenjeno neposredno okolje in enkrat planet Zemlja kot prostor spreminjanja življenja.

\section{SKLEP}

V okviru institucionalne vzgoje in izobraževanja od prvega otrokovega leta starosti do pouka geografije kot samostojnega predmeta $v$ šestem razredu osnovne šole se otrok 
redno srečuje tudi z geografskimi vsebinami. Te so opredeljene v štirih kurikulumih: kurikulumu za vrtce ter v treh šolskih predmetnih kurikulumih - učnih načrtih za predmete Spoznavanje okolja, Družba ter Naravoslovje in tehnika.

Preglednica 3: Področja geografije, vključena v kurikulume od vrtca do petega razreda osnovne šole

Table 3: Fields of geography included in the curriculums from the kindergarten to the fifth grade of primary school

\begin{tabular}{|c|c|c|c|c|c|}
\hline \multirow{2}{*}{\multicolumn{2}{|c|}{ Področja geografije }} & \multirow{3}{*}{$\frac{\mathbf{V V U}}{1-6 \text { let }}$} & \multirow{3}{*}{$\frac{\text { SPO }}{6-8 \text { let }}$} & \multirow{3}{*}{$\begin{array}{c}\text { DRU } \\
\frac{9-10 \text { let }}{X}\end{array}$} & \multirow{3}{*}{$\frac{\text { NIT }}{9-10 \text { let }}$} \\
\hline & & & & & \\
\hline \multirow[t]{7}{*}{ Naravni elementi } & kamnine & & & & \\
\hline & relief & $\mathrm{X}$ & $\mathrm{X}$ & $\mathrm{X}$ & \\
\hline & vode & $\mathrm{X}$ & $\mathrm{X}$ & $\mathrm{X}$ & $\mathrm{X}$ \\
\hline & podnebje & $\mathrm{X}$ & $\mathrm{X}$ & $\mathrm{X}$ & $\mathrm{X}$ \\
\hline & prsti & & & $\mathrm{X}$ & $\mathrm{X}$ \\
\hline & rastje & $\mathrm{X}$ & $\mathrm{X}$ & $\mathrm{X}$ & $\mathrm{X}$ \\
\hline & živalstvo & $\mathrm{X}$ & $\mathrm{X}$ & $\mathrm{X}$ & $\mathrm{X}$ \\
\hline \multirow[t]{3}{*}{ Družbeni elementi } & prebivalstvo & & $\mathrm{X}$ & $\mathrm{X}$ & \\
\hline & naselja & $\mathrm{X}$ & $\mathrm{X}$ & $\mathrm{X}$ & \\
\hline & gospodarstvo & $\mathrm{X}$ & $\mathrm{X}$ & $\mathrm{X}$ & \\
\hline \multirow[t]{4}{*}{ Pokrajine } & lokalna pokrajina & $\mathrm{X}$ & $\mathrm{X}$ & $\mathrm{X}$ & \\
\hline & Slovenija & & $\mathrm{X}$ & $\mathrm{X}$ & \\
\hline & Evropa & & $\mathrm{X}$ & $\mathrm{X}$ & \\
\hline & Zemlja & $\mathrm{X}$ & $\mathrm{X}$ & $\mathrm{X}$ & $\mathrm{X}$ \\
\hline Vzgoja & okoljska vzgoja & $\mathrm{X}$ & $\mathrm{X}$ & $\mathrm{X}$ & $\mathrm{X}$ \\
\hline \multirow[t]{2}{*}{ Geografske spretnosti } & kartografija & $\mathrm{X}$ & $\mathrm{X}$ & $\mathrm{X}$ & \\
\hline & orientacija & $\mathrm{X}$ & $\mathrm{X}$ & $X$ & \\
\hline
\end{tabular}

Viri/Sources: Kurikulum za vrtce (1999); učni načrti za predmete Spoznavanje okolja (2011), Družba (2011), Naravoslovje in tehnika (2011)

Razlaga kratic: VVU-vrtec, SPO - Spoznavanje okolja, DRU-Družba, NIT-Naravoslovje in tehnika

Horizontalno, znotraj posameznih učnih načrtov, je geografija najmanj celovito vključena pri predmetu Naravoslovje in tehnika ter v kurikulumu za vrtec. Pri Naravoslovju in tehniki spoznavajo učenci različne pojavne oblike in naravne procese, povezane z vodo, zrakom, prstmi, rastlinstvom in živalstvom, velik poudarek je tudi na varovanju teh okoljskih sestavin, le redko pa je njihovo spoznavanje povezano s prostorom, s pokrajino. Podobno so v vrtcu ustrezno zastopane naravnogeografske vsebine, razen kamnin in prsti, zelo pomanjkljiva pa sta prostorski in družbenogeografski vidik. 
Predmeta Spoznavanje okolja in Družba imata geografske vsebine precej uravnotežene. Vključujeta skoraj vse pokrajinske elemente in pokrajine, pri slednjih je največji poudarek na lokalni pokrajini in Sloveniji, ne vključujeta pa dovolj spoznavanja kamnin in osnov geomorfologije.

Vertikalno, po področjih geografije, so slabše zastopane naslednje teme: kamnine, prsti, prebivalstvo, pokrajine. Spoznavanje kamnin je vključeno samo v predmet Družba. Tudi relief je v primerjavi z drugimi naravnogeografskimi elementi obravnavan manj poglobljeno. Učni cilji vključujejo le spoznavanje morfoloških tipov reliefa, brez seznanjanja s procesi nastanka in preoblikovanja, kakor učenci spoznavajo druge naravne elemente. $V$ prihodnje si bo potrebno prizadevati, da se v celotno vertikalo bolj neposredno vključi tudi spoznavanje prsti in kamnin. $V$ učni načrt predmeta Naravoslovje in tehnika je potrebno vključiti spoznavanje geoloških in geomorfnih procesov, vodo, zrak, prst, rastlinstvo in živalstvo pa obravnavati tudi kot dele pokrajin s poudarkom na medsebojnem součinkovanju vseh pokrajinskih elementov v duhu vzgoje in izobraževanja za trajnostni razvoj.

Vse večji pomen medpredmetnih področij in medpredmetnega povezovanja nudi $\mathrm{v}$ praksi priložnosti za 'geografske' projekte, saj je geografija kot veda že sama po sebi naravnana na povezovanje različnih družbenogeografskih dejstev, dogodkov, procesov. Učitelji geografije na osnovni šoli lahko v sodelovanju z razrednimi učitelji prispevajo $\mathrm{k}$ celovitejši obravnavi različnih tem že na razredni stopnji.

Pri spreminjanju kurikulumov v prihodnje bi bilo dobro, da bi bili geografi dejavnejši in, če bo le mogoče, vključeni v proces spreminjanja. Potrebno si je prizadevati, da bi bili pri nastanku kurikuluma za vrtce prisotni didaktiki vseh predmetnih področij. Dokler pa velja sedanji kurikulum, ki je načeloma odprt, lahko geografi s svojimi predlogi geografskih vsebin in dejavnosti za otroke pomagamo bogatiti program vrtca, bodisi v neposrednem stiku s predšolskimi vzgojitelji ali prek pisnih prispevkov v različnih medijih. To je pomembno tudi zato, ker v dodiplomskem izobraževanju vzgojiteljic in vzgojiteljev sodeluje geografska stroka samo na primorski univerzi, na univerzah v Ljubljani in Mariboru pa ne.

\section{Viri in literatura}

Batistič Zorec, M., 2002. Učenje v vrtcu. Sodobna pedagogika, 53, 3, str. 24-43.

Batistič Zorec, M., Krnel, D., 2009. Prednost učenja pred poučevanjem. V: Devjak,T., Skubic, D. (ur.). Izzivi pedagoškega koncepta Reggio Emilia. Ljubljana, Pedagoška fakulteta. str. 47-76. URL: http://reggioemilia.pef.uni-lj.si/images/dokumenti/splet_ reggio-emilia.pdf (Citirano 27. 5. 2015).

Bela knjiga o vzgoji in izobraževanju v Republiki Sloveniji. 1995. Ljubljana, Ministrstvo za šolstvo in šport, 343 str.

Izhodišča kurikularne prenove v Republiki Sloveniji. 1996. Ljubljana, Nacionalni kurikularni svet.

Kroflič, R., 2001. Temeljne predpostavke, načela in cilji kurikula za vrtce. V: Marjanovič Umek, L. (ur.). Otrok v vrtcu: priročnik h kurikulu za vrtce. Maribor, Založba Obzorja, str. 7-24. 
Kunaver, J., Resnik Planinc, T., Popit, S., Kolenc Kolnik, K., 2002. Evalvacija kurikularne prenove geografije s posebnim poudarkom na standardih znanja ter načrtovanju in izvajanju vzgojno-izobraževalnega dela-končno poročilo. Ljubljana, Znanstveni inštitut Filozofske fakultete, 58 str. URL: http://www.mizs.gov.si/fileadmin/mizs.gov.si/ pageuploads/podrocje/razvoj_solstva/evalvacija/2000_II/Kunaver_Jurij.pdf (Citirano 27. 5. 2015).

Kurikulum za vrtce: predšolska vzgoja v vrtcih. 2007. Ljubljana, Ministrstvo za šolstvo in šport, Zavod Republike Slovenije za šolstvo, 78 str.

Smernice, načela in cilji posodabljanja učnih načrtov. 2007. Ljubljana, Komisija za spremljanje in posodabljanje učnih načrtov in katalogov znanj za področje splošnega izobraževanja in splošno-izobraževalnih znanj v poklicnem izobraževanju.

Sutherland, P., 1992. Cognitive development today: Piaget and his critics. London, Paul Chapman Publishing Ltd., 216 str.

Učni načrt: Družba. 2011. Ljubljana, Ministrstvo za šolstvo in šport, Zavod RS za šolstvo, 21str. URL: http://www.mizs.gov.si/fileadmin/mizs.gov.si/pageuploads/podrocje/os/ prenovljeni_UN/UN_druzba_OS.pdf(Citirano 27. 5. 2015).

Učni načrt: Naravoslovje in tehnika. 2011. Ljubljana, Ministrstvo za šolstvo in šport, Zavod RS za šolstvo, 33 str. URL: http://www.mizs.gov.si/fileadmin/mizs.gov.si/pageuploads/podrocje/os/prenovljeni_UN/UN_naravoslovje_in_tehnika.pdf (Citirano 27. 5. 2015).

Učni načrt: Spoznavanje okolja. 2011. Ljubljana, Ministrstvo za šolstvo in šport, Zavod RS za šolstvo, 31 str. URL: http://www.mizs.gov.si/fileadmin/mizs.gov.si/pageuploads/podrocje/os/prenovljeni_UN/UN_spoznavanje_okolja_pop.pdf (Citirano 27. 5. 2015).

Žakelj, A., 2014a. Posodabljanje kurikularnega procesa v gimnazijski praksi. Ljubljana, Zavod Republike Slovenije za šolstvo. URL: http://publikacija.k56.si/strokovnjaki/ index.html (Citirano 27. 5. 2015).

Žakelj, A., 2014b. Posodabljanje pouka v osnovni šoli in gimnaziji (2006-2013). V: Žakelj, A., Borstner, M. (ur.). Posodobitev kurikularnega procesa na osnovnih šolah in gimnazijah. Zbornik prispevkov zaključne konference in predstavitev predmetno razvojnih skupin. Ljubljana, Zavod za šolstvo, str. 9-24. URL: http://www.zrss.si/pdf/ PKP-zbornik-prispevkov-zakl-konf.pdf (Citirano 27. 5. 2015).

\section{GEOGRAPHY IN KINDERGARTENS AND AT THE LOWER LEVEL OF PRIMARY SCHOOL IN SLOVENIA}

\section{Summary}

The aim of this paper is to highlight and partially evaluate geography teaching at lower levels of education. We set forth the following questions: to what extent and with what contents and activities is geography incorporated into the curriculums from preschool period to the fifth grade; what is its quantity relation to other subjects; what curriculum changes are to be sought in future reforms? With the use of semi-quantitative and 
qualitative approach, we analysed curriculums that incorporated geographical contents. Encoding categories comprised landscape elements, regions, orientation and cartography.

Kindergarten curriculum is process- and development-oriented. It emphasizes openness, a diversified and balanced offer of various fields, as well as autonomy of kindergartens. It determines five fields of activities. These "constitute a framework within which the contents and activities are a professional offer for educators. The educators implement the curriculum by employing various methods of integrating, upgrading and supplementing the proposed contents and activities." (Kurikulum za vrtce, 2007, p. 25).

Kurikulum za vrtce [Curriculum for Kindergartens] was the result of the cooperation that included twenty-nine experts, but not e.g. primary-level experts, subject didacts. Thus, there is no geographer, historian, sociologist, etc. among the authors, which is also reflected in the curriculum contents. Geographical objectives and activities were found in three fields - society, nature and mathematics. The field of society includes two geographical objectives out of 19 and seven activities out of 23. Most of the proposed themes are not spatially addressed and geographical activities are as follow: children become acquainted with their home environment, various institutions, professions, geographical and cultural environments; they put themselves in the positions of others on the basis of their contacts with peers from other places and lands and with the help of books, TV, etc. The field of nature includes eight geographical objectives out of 37, covering the following contents: living and nonliving nature in mutual co-dependence, environmental protection, weather phenomena, planet Earth, spatial planning, the importance of geographical position, water. Spatial orientation and cartography are part of mathematics, and the only two geographical objectives out of 16 (Table 1).

Regarding the learning about landscape elements, natural-geographical elements are better integrated than human-geographical ones and regional geography is the least represented of all. There should be a greater inclusion of familiarizing with stones, soils, population-related themes, economy is largely ignored, and even more so various types of landscape.

The primary-school curriculums include geography as an independent subject from the sixth to the ninth grade. However, in the learning process, geographical learning objectives and contents are traditionally included from the first grade onwards.

From the first to the third grade of primary school, natural and social science themes are part of school subject called Environment. Geographical learning objectives and contents include all basic geographical fields and are well represented in comparison to other scientific fields. Out of 183 teaching objectives there are 47 geographical ones. Roughly one half is contained in two geographical thematic clusters, one quarter in natural science themes and one quarter in social science themes (Figure 1). This points to a suitable representation of learning objectives, through which pupils of 6-8 years obtain basic geographical knowledge, especially of their immediate environment, and expand their spatial orientation to Slovenia, Europe and the world.

The subject Society is part of the curriculum of the fourth and fifth grade of primary school and is the continuation of the subject Environment, which is in the second educational period divided into Society on the one hand and Natural sciences and technology on 
the other. The main share of geographical learning objectives is contained in the subject Society, as much as $42 \%$ (Table 2). The contents include human-geographical, physicalgeographical and regional-geographical contents and activities, as well as orientation and cartography. Physical-geographical contents are linked to learning about various types of landscape which the pupils now learn integrally for the first time. Emphasis is on familiarizing with the domestic landscape and other types of Slovenian landscapes. The pupils learn also about the EU from the political point of view.

Objectives contained in the syllabus Natural sciences and technology are much more divided, amounting to three times more than in the curriculum Society. A quarter of the learning objectives out of the 54 may also be considered as geographical. They provide a detailed presentation of waters, weather, soils, fauna, flora - also from the perspective of environmental education. However, they do not deal with rocks (save in connection with soil) or relief. As a rule, learning objectives do not associate phenomena with the space (Table 3).

Horizontally, within individual curriculum, geography is the least integrally incorporated into Natural sciences and technology (followed by kindergarten) and is given more comprehensive presentation in the subject Environment. The geographical contents contained in the subjects Environment and Society are quite balanced. The said subjects include nearly all geographical elements and different areas - the latter with the main emphasis on the local area and Slovenia. However, they do not include enough learning of rocks, and sustainable development education is only declaratively included in curriculums. Vertically, by geographical fields, the less represented themes are as follow: rocks, soils, population, landscapes. Familiarization with rocks is included only in the curriculum Society. Similarly, relief is covered in less detail than other natural-geographical contents. Learning objectives include only learning about the morphological types of relief, while ignoring the processes of evolution and transformation. By learning about the waters, weather, soil, flora and fauna, the pupils get acquainted with various natural processes, including in relation to one another.

In the future it is recommendable for geographers to be more active in changing curriculum for kindergarten and, if possible, to be more involved in the changing process. All efforts should be made to include the didactics of all subject areas in developing the curriculum for kindergartens. However, as long as the existing - principally open-ended - curriculum remains valid, geographers as well as parents can still do many things. For instance, they may propose various geographical activities for children to the educators and encourage them to discover the geographical characteristics of the kindergarten's immediate surroundings as well as more distant landscapes. This is important also because only at one Slovenian university a higher geography teacher lectures on the program for the education of preschool teachers. 